\title{
MICRONUTRIENT DEFICIENCIES IN FOOD AID BENEFICIARIES: A REVIEW OF SEVEN AFRICAN COUNTRIES
}

\section{Natalie Drorbaugh $^{1}$ and Charlotte G. Neumann ${ }^{1,2}$}

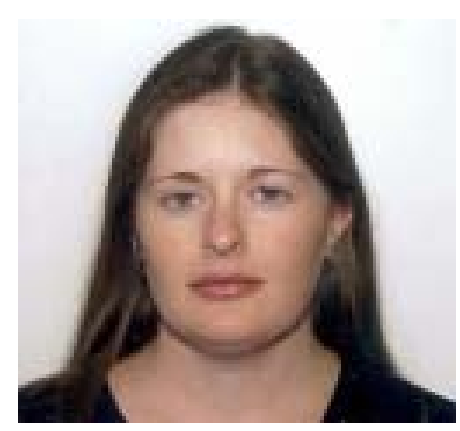

Natalie Drorbaugh

*Corresponding author Email: ndrorbaugh@alum.wellesley.edu

1 c/o Dr. Charlotte Neumann, Department of Community Health Sciences, UCLA School of Public Health, P.O. Box 951772, Los Angeles, CA 90095, USA.

${ }^{2}$ Department of Pediatrics, David Geffen School of Medicine, University of California, Los Angeles. 


\section{ABSTRACT}

In order to identify micronutrients likely to be deficient in food aid beneficiary populations and to guide the formulation of food aid products, this review was undertaken to summarize published data about micronutrient deficiencies in food aid beneficiaries as compared to the general population in seven African countries (Niger, Ethiopia, Kenya, Uganda, Rwanda, Zambia, and Zimbabwe). These countries were identified by SUSTAIN as having received significant quantities of United States Public Law 480 (P.L. 480) Title II fortified and blended food aid products from 20012006. Information was drawn from agency reports, personal communications, national survey data, and academic literature, primarily published since the year 2000. Among food aid beneficiaries in these countries, vitamin A and iron deficiencies were most prevalent. Deficiencies in zinc, folate (particularly in pregnancy), vitamins B-12, C, and $\mathrm{D}$, thiamine, riboflavin, and calcium are likely prevalent based on low intake and physical signs of deficiency documented in the literature. In some cases, food aid rations provide insufficient quantity and quality of micronutrients, especially when used over extended periods of time as the sole food source. In nearly all the countries reviewed, deficiencies in vitamin $\mathrm{A}$, iron, iodine, and other micronutrients are also quite common in the general population (those not receiving food aid). Micronutrient status information for food aid beneficiaries came mainly from studies in refugee/emergency settings, with few published studies found documenting the nutritional status of non-emergency food aid recipients. Useful insights were obtained by the review although limited micronutrient data were available for food aid beneficiaries. The micronutrient status of food aid beneficiaries should be monitored, with food aid products formulated to match the deficiencies present. Where possible, the use of anthropometry, simplified dietary assessment methods, and physical inspection are recommended to estimate micronutrient status where biochemical tests are not feasible. Agencies that currently monitor the nutritional status of food aid recipients are urged to make reports available to researchers, relief agencies, and the public.

Key words: Food-aid, Africa, micronutrients, deficiencies, evaluation 


\section{INTRODUCTION}

This literature review was undertaken in order to summarize existing information on micronutrient deficiencies in food aid beneficiaries (FAB) and the general population (GP) in seven countries African countries (Niger, Ethiopia, Kenya, Uganda, Rwanda, Zambia, and Zimbabwe) to prioritize those micronutrients likely to be deficient in FAB populations and to guide the formulation of food aid products. These seven countries were identified by the agency which commissioned the review (SUSTAIN) as countries that received significant quantities of U.S. Public Law (P.L.) 480 Title II fortified and blended food aid products from 2001-2006. The review was commissioned as part of the Food Aid Quality Enhancement Project to improve understanding of the nutritional needs of $F A B$ populations and to prioritize those micronutrients likely to be deficient in FAB populations to guide the formulation of food aid products. An understanding of the micronutrient needs of FAB is important to direct the formulation of these products, especially given the substantial investments made by non-profit and governmental agencies in food aid.

Food aid programs are varied and serve wide-ranging goals. Currently, a large proportion of food aid is directed toward emergency and refugee settings in which food aid often serves as the primary source of food for populations with frequently limited access to other sources of food. In these settings, it is important that food aid products provide essential micronutrients. Prevalence of deficiency is likely greater in FAB, especially those that depend solely on food rations to meet their nutritional needs. This is especially true for populations relying on rations for extended periods of time and lacking other means of obtaining food items such as animal source foods (ASF) and fresh fruits and vegetables [1]. Food aid rations tend to consist mainly of grain products; with a small portion consisting of fortified blended food products such as corn soya blend (CSB). Some reports have indicated that food aid rations provide insufficient micronutrients such as riboflavin, calcium, and vitamin $\mathrm{C}$, in part due to insufficient total quantity of food [2,3]. Table 1 provides summary nutritional information regarding nutritional properties of common food aid commodities $[4,5]$. In non-emergency food aid programs such as food for work, food for peace, and school feeding programs, food aid serves as a supplement to the normal diet and is not expected to fulfill all nutritional needs. Given the different types of populations served by food aid programs, the nutritional needs and status of beneficiaries are quite heterogeneous.

In nearly all the countries reviewed, deficiencies in vitamin A, iron, iodine, and other micronutrients such as zinc and calcium are common in the general population (GP). Vitamin A deficiency (VAD) is endemic throughout Africa, is the leading cause of childhood preventable blindness, and contributes to the risk of morbidity and mortality from infectious disease in children and pregnant women [6]. Iron deficiency, with and without anemia, may be the "most prevalent micronutrient deficiency in emergencies" as foods containing more readily absorbed heme iron are seldom part of cereal-based food aid diets, and iron is not readily bioavailable in many cereal-based diets if phytate and fiber content is high [6]. Few studies directly assess iron

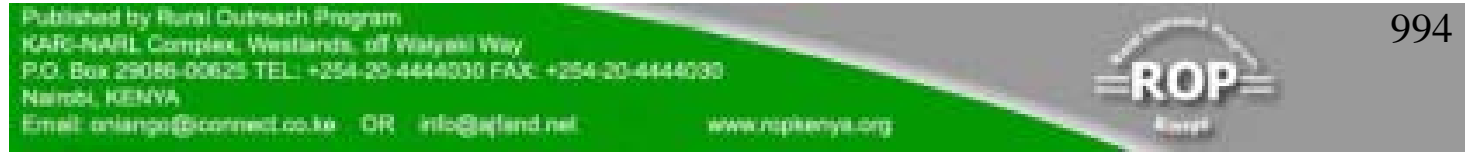


deficiency per se. Anemia, which is most commonly reported, may be caused by multiple other nutrient deficiencies as well as congenital anemia and malaria.

Zinc deficiency is assumed to be widespread in areas where diets lack diversity and non-dairy ASF [7]. An estimated $20 \%$ of the world's population is at risk for zinc deficiency, with higher risk for deficiency (34.6\%) in Sub-Saharan Africa [8]. Risk for zinc deficiency is likely high in pregnant women in developing countries, as typical diets often supply inadequate bioavailable zinc [9]. Deficiencies in other micronutrients are discussed in more detail in the results reported below.

\section{METHODS}

Prevalence data for micronutrient deficiencies were obtained from Demographic and Health Survey reports, national survey data, and other publications. The World Health Organization (WHO) Vitamin and Mineral Information System was utilized to identify relevant studies. Journal articles (primarily post 2000) were located utilizing databases, references cited in reports, and other published literature. A number of nongovernmental and governmental agencies were contacted to request reports and data. Those agencies that supplied information are listed in Table 2. Food aid beneficiaries were considered to be those reported to be receiving food aid from any source.

\section{RESULTS}

The available data on the status of the general population (GP) and FAB populations in the countries reviewed suggest significant deficiencies in key micronutrients.

\section{Vitamin A}

The prevalence of vitamin A deficiency (VAD), defined as low serum retinol concentrations $(<0.7 \mu \mathrm{mol} / \mathrm{L})$, in both the GP and FAB is generally high and indicates varying, but significant, levels of deficiency in most countries.

Studies of VAD in FAB are summarized in Table 3. In Ethiopia prevalence values from studies in FAB populations are much higher than the $10 \%$ cutoff value used to define VAD as a serious public health issue in a population [10]. This suggests that VAD poses a serious public health issue in these populations, with variations in prevalence seen among refugee camps. Six to 59 month-old children in Fugnido and Kebribeyah camps had mean retinol concentrations of $0.74 \pm 0.2$ and $0.88 \pm 0.2$ $\mu \mathrm{mol} / \mathrm{L}$, respectively [11]. A 2001 micronutrient survey among Somali refugee children in Ethiopia showed high VAD prevalence (20.5\%) [12]. In Kenya, a 1998 survey in adolescent refugees in Kakuma camp documented VAD in 15\% and night blindness in $24 \%$ [13]. A school-based supplementary feeding program using micronutrient-fortified food was implemented in this camp during the 1990s and was ongoing in 1998. In preschool children in Kakuma, a survey in 2000-2002 found a mean retinol concentration of $0.72 \pm 0.2 \mu \mathrm{mol} / \mathrm{L}$, and VAD in $\sim 50 \%$ of these children [11]. In Uganda, only one study of vitamin A status in Ugandan FAB was found. More than half the children aged 6-59 months in Acholpil refugee camp had VAD, and mean serum retinol concentration was $0.66 \pm 0.2 \mu \mathrm{mol} / \mathrm{L}$ [11]. In Zambia, a 


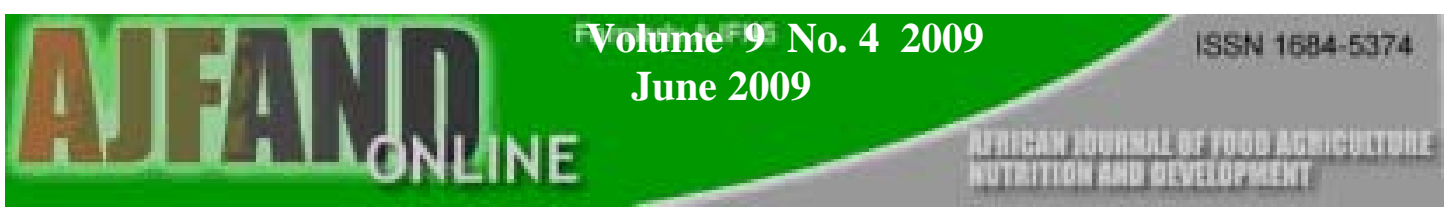

micronutrient survey in Nangweshi refugee camp in 2004 showed VAD in 20.3\% of adolescents (10-19y). This was lower than the prevalence in 2003 before a fortification program was introduced (46.4\%) [14]. No reports documenting the vitamin A status of FAB in Niger, Rwanda, and Zimbabwe were found.

Data on VAD status of the GP is summarized in Table 4 [11, 12, 15-34]. In general, FAB children seem to experience a greater VAD prevalence than GP children based upon indicators such as night blindness, though caution should be used in comparing prevalence rates from the two populations. In countries for which data was available, the prevalence values for Bitot's spots and night blindness exceed World Health Organization cutoff points used to indicate the presence of public health problems ( $0.5 \%$ prevalence for Bitot's spots and $1 \%$ for night blindness in children) [35]. In all countries for which data were available, VAD prevalence based on serum retinol concentrations below the reference cut-off point $(0.7 \mu \mathrm{mol} / \mathrm{L})$ was more than $10 \%$ in children under age 6 in the GP.

\section{Iron}

Anemia from multiple etiologies is reported. The majority of anemia is probably related to iron deficiency; however, multiple etiologies contribute. Iron deficiency anemia (IDA) is reported when values were available. The WHO criteria for assessing the public health significance of anemia (from all sources) within a population is based on prevalence rates: $>40 \%$ constitutes a severe public health concern; $20-40 \%$ moderate public health concern; and 5-20\% a mild public health concern [36, 37].

Results from studies of anemia and iron status in FAB are shown in Table 5. In refugee settings in Ethiopia anemia appears to present a severe public health problem among FAB children with prevalence values ranging from $12.8-62.9 \%$. Prevalence varies from camp to camp making it difficult to generalize to all FAB. Malaria also contributes to anemia, with $42.0 \%$ prevalence of malaria documented in a sub-sample in Fugnido camp [11]. Based on available data, anemia represents a severe public health problem in children, adolescents, and pregnant women in camps studied in Kenya, with iron deficiency accounting for a considerable proportion. In Kakuma camp in 2001 and 2005, anemia was documented in $>50 \%$ of children younger than five years old, with slide-positive malaria infection prevalence of $6.7 \%$ [3, 11]. Almost half of adolescent refugees in this camp were found to be anemic, and $62.5 \%$ of anemic adolescents tested for transferrin receptor concentration were iron deficient [13]. Anemia was highly prevalent in pregnant women (75\% in Dadaab camp) [3]. Food baskets provided in 2 camps (Kakuma and Dabaab) in Kenya provided $81 \%$ of the Food and Agriculture Organization/Word Health Organization recommended iron intake [3]. In Alcholpii refugee camp in Uganda anemia was a severe public health problem in children (6-59 months), with anemia documented in $72.9 \%$ (mean hemoglobin $(\mathrm{Hb}) 98 \pm 17 \mathrm{~g} / \mathrm{L}$ ) and iron deficiency (serum-soluble transferrin receptor (sTfR) concentration $>8.5 \mathrm{mg} / \mathrm{L}$ ) in $75 \%$ [11]. Malaria prevalence was high $(60.0 \%)$ [11]. Anemia prevalence in adolescents and women was lower, indicating a moderate public health problem [11]. In Zambia, anemia was documented in children, adolescents, and non-pregnant women in one refugee camp in Zambia. Prevalence values for total anemia in all three groups were $\sim 25 \%$ following a year-long food 


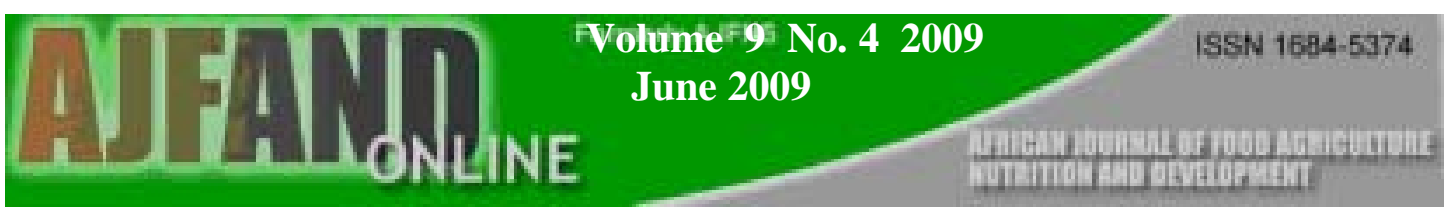

fortification program [14]. No documentation of anemia and iron status in food aid beneficiaries in Niger, Rwanda, or Zimbabwe was found.

Table 6 summaries the anemia and iron status of the GP [16-25]. In children under age five years, anemia represents a severe public health problem (prevalence $>40 \%$ ) for the GP as well as for FAB (in countries where data was available). The anemia status of $F A B$ varies from location to location, even within a specific country, with some FAB prevalence values below and some above the values for the GP. Iron deficiency was only assessed in FAB in two countries (Ethiopia and Kenya). In Kenya, iron deficiency appears to be more prevalent in FAB than in the GP.

\section{Iodine}

Total goiter prevalence (TGP), which includes visible and palpable goiter, and urinary iodine (UI) levels are often used to assess iodine deficiency (ID). A TGP greater than $30 \%$ in the population indicates of a severe public health iodine deficiency problem [38]. Median UI levels are used to define the public health severity of ID: mild public health problem $(50-99 \mu \mathrm{g} / \mathrm{L})$; moderate public health problem $(20-49 \mu \mathrm{g} / \mathrm{L})$; severe public health problem $(<20 \mu \mathrm{g} / \mathrm{L})$ [38]. The percent of the population with UI levels below the $100 \mu \mathrm{g} / \mathrm{L}$ cut-off level indicates prevalence of ID [38].

Surveys conducted in 2001 among adolescent refugees in two long-term refugee camps in Ethiopia revealed high median UI concentrations $(1074 \mu \mathrm{g} / \mathrm{L}$ in Fugnido and $254 \mu \mathrm{g} / \mathrm{L}$ in Kebribeya) [39]. Hence, ID does not seem to represent a public health problem in the two populations studied. Individual UI concentrations ranged from 14 to $8400 \mu \mathrm{g} / \mathrm{L}$ [39]. Prevalence of visible goiter was low (1.3\%), and iodized salt rations distributed by WFP were calculated to contribute up to $440 \mu \mathrm{g}$ iodine/person/day [39]. A 2001 survey conducted in long-term refugees in Kakuma camp in Kenya showed a high median UI concentration $(620 \mu \mathrm{g} / \mathrm{L})$ [39]. It appears that iodine consumption is more than adequate in FAB in this camp, though no data was found for other camps. In Uganda, a 2001 survey among long-term refugees in the Acholpii camp showed a median UI concentration of $726 \mu \mathrm{g} / \mathrm{L}$ (range: 150-3400 $\mu \mathrm{g} / \mathrm{L}$ ) [39]. Concentrations for all adolescents studied were over the $100 \mu \mathrm{g} / \mathrm{L}$ deficiency cutoff point. Visible goiter prevalence was 0.4\% [39]. A 2003 survey among long-term adolescent refugees in the Nangweshi camp in Zambia revealed a median UI concentration of $570 \mu \mathrm{g} / \mathrm{L}$ (range: 65-6630 $\mu \mathrm{g} / \mathrm{L}$ ) [39]. Visible goiter prevalence was $0 \%$. Hence, ID is not a problem in the population studied in this camp. No documentation of the iodine status of FAB in Niger, Rwanda, or Zimbabwe was found. The data available for FAB in refugee settings in Ethiopia, Kenya, Uganda, and Zambia suggest that excess iodine, rather than insufficient iodine, is of concern based on UI levels.

In the GP, the prevalence of iodine deficiency varies from country to county based on data available for urinary iodine concentration, with the highest prevalence in Zambia and Ethiopia, followed by Kenya, Zimbabwe, and Uganda (Table 7) [27, 40-44]. 


\section{Zinc}

No assessments of the zinc status of FAB populations in the countries reviewed here were found. In the general population in Ethiopia and Kenya, a limited number of studies were found documenting zinc status. One study of pregnant women $(n=99)$ in rural Southern Ethiopia documented low plasma zinc concentrations in $72 \%$, with $99 \%$ at risk for inadequate zinc intake given their low dietary intake of zinc and ASF [45]. In a study of 5-11 month-old Ethiopian infants, zinc concentration in breast milk of mothers of stunted infants $(9.2 \mu \mathrm{mol} / \mathrm{L} \pm 0.3)$ was found to be significantly less than that in the milk of mothers of non-stunted infants $(10.4 \mu \mathrm{mol} / \mathrm{L} ; P=0.02)$ [46]. In Kenya, a 1999 national micronutrient survey revealed a geometric mean of serum zinc concentration ranging from $55.2-86.1 \mu \mathrm{g} / \mathrm{dL}(\mathrm{n}=541$ children) [20]. The overall sample mean was $65.1 \mu \mathrm{g} / \mathrm{dL}$, and the proportion of low serum zinc $(<65 \mu \mathrm{g} / \mathrm{dL})$ was $50.8 \%$ [20]. These results indicate risk of zinc deficiency in $\sim 50 \%$ of the population sampled. Another study of 555 rural school children in Embu district showed low baseline serum zinc concentrations $(<10.7 \mu \mathrm{mol} / \mathrm{L})$ in $65.6 \%$ of the children [16].

\section{Folate}

No data was found on folate deficiency in FAB in the countries included in this review. Folate deficiency was not documented in studies of the general population in Kenya during the 1980s, and a later study of school-aged children in rural Kenya found a high percentage of low normal values but almost no low plasma folate concentrations [16]. A study of 1669 pregnant women in Harare, Zimbabwe revealed a mean serum folate value of $11.6 \mathrm{nmol} / \mathrm{L}$ which varied significantly by season, as did the proportion of women with folate values less than the $<6.7 \mathrm{nmol} / \mathrm{L}$ cut-off value for deficiency [47].

\section{Other Micronutrients}

Thiamine (Vitamin B-1) - Beriberi outbreaks have occurred in refugees and internally displaced persons (IDP) dependent on food aid, with a recent outbreak reported in Cote d'Ivoire [48]. In the countries included in this review, forty cases of beriberi were observed in 1993 among refugees in Ethiopia, and deficiency was reported in Kenyan IDP in 2000 [6, 49]. The presence of at least one confirmed clinical case in a population is considered a mild public health problem [50]. The number of refugees at risk is unclear, making it difficult to assess the magnitude of the public health problem.

Riboflavin (Vitamin B-2) - No reports of riboflavin deficiency in FAB were found. Riboflavin deficiency is more prevalent in areas where few ASF are consumed [51]. In a study of 555 rural Kenyan school children (ages 5-14y) consuming a primarily plant-based diet, $24.3 \%$ had red blood cell riboflavin concentrations $<170 \mu \mathrm{mol} / \mathrm{L}$ at baseline [16]. In Zimbabwe, riboflavin deficiency (erythrocyte glutathione reductase activation coefficient of 1.4+) was documented in $33.8 \%$ of 154 women at increased risk for preeclampsia attending an antenatal clinic [52]. These studies suggest deficiency in the general population.

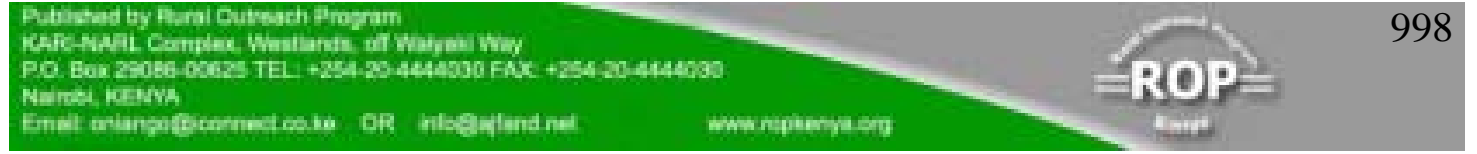


Niacin (Vitamin B-3) - Pellagra has been seen in refugee and IDP populations reliant upon maize and without beans or groundnuts, with the presence of one confirmed clinical case in a population considered a mild problem $[6,50]$. A pellagra prevalence of $1.5 \%$ was reported in Zimbabwe in 1988 [53]. However, no recent reports of outbreaks were found in the other countries reviewed here.

Vitamin B-12 (cobalamin) - No studies of vitamin B-12 status in FAB were found. Low plasma vitamin B-12 concentrations have been documented in some of the countries reviewed. In rural Kenyan schoolchildren, $30.5 \%$ had severely low concentrations $(<125 \mathrm{pmol} / \mathrm{L})$ and $37.7 \%$ had moderately low concentrations (125$221 \mathrm{pmol} / \mathrm{L}$ ) [16]. An earlier study in Zimbabwe showed vitamin B-12 deficiency as the main cause of megaloblastic anemia [54].

Vitamin C (ascorbic acid) - Clinical vitamin C deficiency (scurvy) has been documented in populations reliant on food aid for long periods of time without access to fresh vegetables and fruit [51]. Scurvy was reported in Ethiopia in 1993 and 1994 [55]. Deficiency resulting in scurvy was reported in Kenyan populations dependent on food aid in 1994 and 1995 [6]. In Somali refugees in Kenya, a major outbreak was observed in 1994, an epidemic in 1996, and cases reported from 1997-1998 [55]. More recent reports were not found in the countries reviewed.

Vitamin D - Published reports of rickets in FAB were not found. In Ethiopia, cases of rickets in children have been found to result mainly from inadequate vitamin $\mathrm{D}$ intake and lack of exposure to sunshine [56]. A resurgence of rickets has been documented in toddlers in rural Kenya with deficiencies in vitamin D and calcium as probable contributing factors [57].

Calcium - A study of 99 pregnant women in the general population of rural Southern Ethiopia documented risk for inadequate dietary intake of calcium in $74 \%$ [45]. A study in Ethiopian children in the general population documented low calcium intake ( $\sim 650 \mathrm{mg}$ ) as compared to the recommended daily allowance (800 $\mathrm{mg}$ for age group) [56]. Cases of rickets reported in Kenyan toddlers indicate both calcium and vitamin D deficiency as contributing factors [57].

Selenium - No deficiency prevalence values were found for FAB. A 1993 study in Niger concluded that, given selenium concentrations in breast milk and maternal serum, the selenium status in the general population of Niger was adequate [58]. A cross-sectional study of 318 women seropositive for HIV Type 1 in the general population of Mombasa, Kenya, showed selenium deficiency (serum selenium concentration $<85 \mu \mathrm{g} / \mathrm{L}$ ) in $11 \%$ [59].

\section{DISCUSSION}

Data on prevalence of deficiencies indicate that vitamin $A$ and iron deficiencies continue to represent significant public health problems in the GP and FAB in the countries under review. In FAB, excessive iodine intake may be problematic based on high urinary levels. Calcium, iron, zinc, riboflavin, and vitamin B-12, which are found

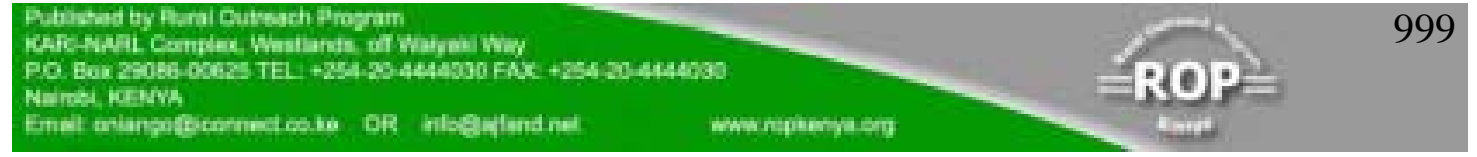


in ASF, should receive particular attention, as food rations are often low in ASF. It is difficult to draw definitive conclusions regarding the micronutrient status of FAB populations in the countries reviewed due to the limited amount of information available on the micronutrient status of FAB. This review includes beneficiaries of food aid from any source, although most information on FAB micronutrient status was obtained from studies in refugee/emergency settings as few micronutrient studies in non-emergency FAB were found. Data collected in refugee/emergency situations cannot be generalized to all $\mathrm{FAB}$ as levels and types of food aid received vary greatly between FAB populations. Additionally, data for FAB in one refugee camp do not necessarily reflect the nutritional status of all refugee FAB as local circumstances and conditions differ. In some cases, refugee camps include populations from other countries.

Except for World Food Programme (WFP) reports, few articles published in the academic literature included information on the source of food aid or its nutritional content. Results are not readily comparable due to use of different indicators and sampling frames and study populations with dissimilar local circumstances. Many agencies contacted for this review were unaware of studies of the micronutrient status of FAB, particularly after receipt of food aid. A number of logistical and budgetary constraints impede assessment of micronutrient status in field settings. Data on nutritional status of refugee populations is often limited to anthropometric data and obvious clinical signs, making it difficult to assess the micronutrient status of these populations. Some WFP/United Nations High Commissioner for Refugees Joint Assessment Mission (JAM) reports contain limited information on the nutritional status of refugees. However, JAMs do not always include a nutritionist with expertise in assessment [1].

The WFP conducts annual surveys in many refugee camps to assess acute malnutrition using anthropometric indicators; however, these surveys are cross sectional and rarely assess micronutrient status [1]. Some baseline studies in populations before receiving food aid have been published, but assessments of the impact of food aid on micronutrient status of beneficiaries are difficult to find. School feeding programs do not commonly monitor nutritional status as an outcome, using instead school attendance as an indicator of success. One WFP evaluation was found that assessed a nutritional indicator (stunting) in FAB children as compared to the general population [60]. Other nongovernmental organizations (NGO) providing food aid that were contacted likewise did not collect data on the micronutrient status of FAB. While some NGOs do assess nutritional status using anthropometric data and screen for anemia and night blindness in some beneficiaries, very few assess deficiencies of other micronutrients such as zinc, calcium, vitamin D, and the $\mathrm{B}$ vitamins. Moreover, results from NGO nutrition surveys are not commonly published or widely disseminated. Most nutritional status studies that have been conducted target the general public and children $<5$ years of age who may or may not be receiving food support. 


\section{CONCLUSIONS}

More data are needed on the macro- and micronutrient impact of feeding on FAB participating in food aid programs, including school feeding and maternal and child nutrition programs. More evaluations of the FAB nutritional status and wider dissemination of results are critically needed. Numerous logistical, staffing, and funding constraints make assessment of micronutrient status difficult, especially in settings where laboratory facilities and trained staff may be unavailable and the population is constantly changing. However, collaboration with government agencies and universities may provide resources for assessment of micronutrient status.

Nutritional outcomes that can be assessed without complex tests include height and weight to assess growth and energy intake in children and zinc (indirectly) in the case of height, weight gain during pregnancy, and reported birth weight. Hemoglobin can be assessed on site with equipment such as Hemocue or less expensive, although less accurate, methods. Microanalysis methods exist for selected micronutrients that allow collection of blood samples on filter paper for later laboratory analysis. These biochemical micronutrient assessments provide valuable information. Food frequency questionnaires can be used to estimate intake of macro and micronutrients. Additionally, use of simple physical inspection can document signs of moderate to severe deficiencies, which represent the tip of the iceberg as less severe cases are likely present. This information can guide future interventions. Agencies and governments using food aid may already be assessing the nutritional status of beneficiaries, but information is not always available for public review. Such information should be widely circulated as it would be extremely useful for aid agencies and governmental policy makers to better understand micronutrient deficiencies present in $\mathrm{FAB}$ and improve the nutrient content of food aid the nutrition situation of FAB.

\section{ACKNOWLEDGEMENTS}

The authors acknowledge SUSTAIN for funding the original review as part of the Food Aid Quality Enhancement Project to improve aid food quality and improve micronutrient delivery to beneficiaries of U.S. food aid commodities. The authors wish to thank Lisa Fleige for her guidance and assistance in the preparation of this manuscript and Pia Chaparro for her feedback. 


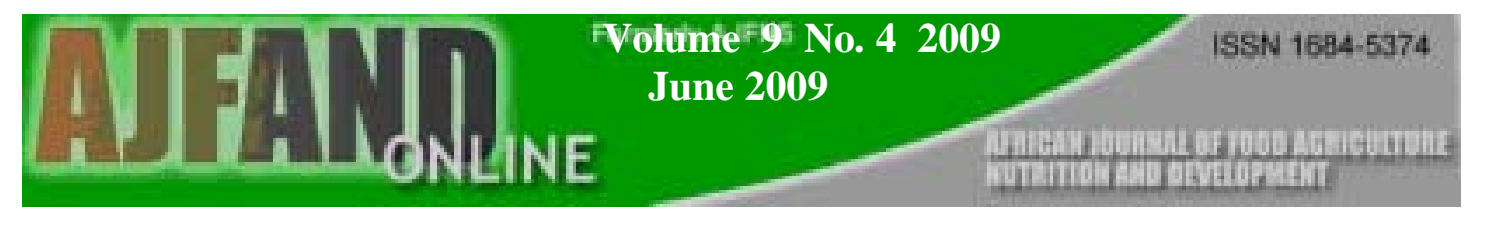

Table 1: Nutritional Content per $100 \mathrm{~g}$ for selected food aid commodities

Energy Protein Fat $\mathrm{Ca}$ Iron Vit. A Thiamine Riboflavin Niacin Folate Vit. C $\begin{array}{llllllllll}(\mathrm{kcal}) & (\mathrm{g}) \quad(\mathrm{g}) & (\mathrm{mg}) & (\mathrm{mg}) & (\mu \mathrm{g}) & (\mathrm{mg}) & (\mathrm{mg}) & (\mathrm{mg}) & (\mu \mathrm{g}) & (\mathrm{mg})\end{array}$

\section{Cereals}

\begin{tabular}{lccccccccccc}
\hline Wheat & 330 & 12.3 & 1.5 & 36 & 4 & 0 & 0.3 & 0.07 & 5 & 51 & 0 \\
Rice & 360 & 7 & 0.5 & 7 & 1.2 & 0 & 0.2 & 0.08 & 2.6 & 11 & 0 \\
Sorghum/Millet & 335 & 11 & 3 & 26 & 4.5 & 0 & 0.34 & 0.15 & 3.3 & $\mathrm{U}$ & 0 \\
Maize & 350 & 10 & 4 & 13 & 4.9 & 0 & 0.32 & 0.12 & 1.7 & $\mathrm{U}$ & 0
\end{tabular}

\section{Processed Cereals}

\begin{tabular}{lccccccccccc}
\hline Maize meal & 360 & 9 & 3.5 & 10 & 2.5 & 0 & 0.3 & 0.1 & 1.8 & $\mathrm{U}$ & 0 \\
Wheat flour & 350 & 11.5 & 1.5 & 29 & 3.7 & 0 & 0.28 & 0.14 & 4.5 & $\mathrm{U}$ & 0 \\
Bulgur wheat & 350 & 11 & 1.5 & 23 & 7.8 & 0 & 0.3 & 0.1 & 5.5 & 38 & 0
\end{tabular}

Blended Food

Corn Soya

380

$18 \quad 6$

$513 \quad 18.5 \quad 500$

0.65

0.5

$\begin{array}{lll}6.8 & \mathrm{U} & 40\end{array}$

Blend

Wheat Soya

370

$\begin{array}{lllll}20 & 6 & 750 & 20.8 \quad 498\end{array}$

1.5

0.6

$9.1 \mathrm{U}$

40

Blend

\section{Dairy Products}

Dried Skim

360

36

11257

$1 \quad 1500$

0.42

1.55

$50 \quad 0$

Milk (enriched)

Dried Whole

500

25

27

912

$0.5 \quad 280$

0.28

1.21

0.6

37

0

Milk 


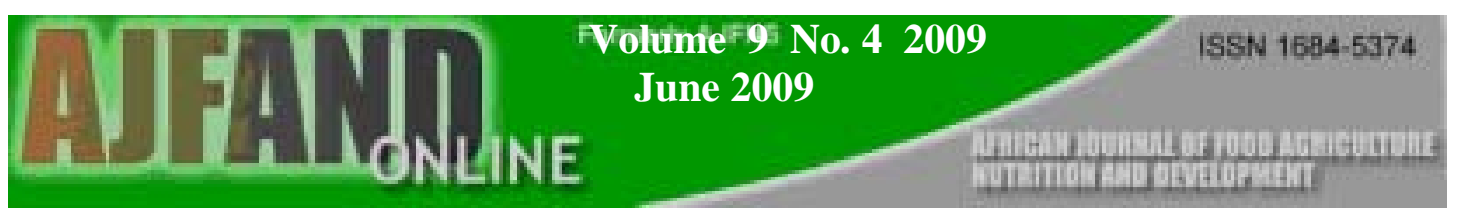

Energy Protein Fat $\mathrm{Ca}$ Iron Vit. A Thiamine Riboflavin Niacin Folate Vit. C

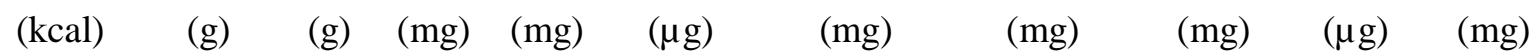

\begin{tabular}{|c|c|c|c|c|c|c|c|c|c|c|c|}
\hline \multicolumn{12}{|l|}{ Meat and Fish } \\
\hline Canned meat & 220 & 21 & 15 & 14 & 4.1 & 0 & 0.2 & 0.23 & 3.2 & 2 & 0 \\
\hline Dried salted & 270 & 47 & 7.5 & 343 & 2.8 & 0 & 0.07 & 0.11 & 8.6 & $\mathrm{U}$ & 0 \\
\hline \multicolumn{12}{|l|}{ fish } \\
\hline Canned fish & 305 & 22 & 24 & 330 & 2.7 & 0 & 0.4 & 0.3 & 6.5 & 16 & 0 \\
\hline \multicolumn{12}{|l|}{ Oils and Fats } \\
\hline Vegetable oil & 885 & - & 100 & 0 & 0 & 0 & 0 & 0 & 0 & 0 & 0 \\
\hline \multicolumn{12}{|l|}{ Pulses } \\
\hline Beans & 335 & 20 & 1.2 & 143 & 8.2 & 0 & 0.5 & 0.22 & 2.1 & 180 & 0 \\
\hline Peas & 335 & 22 & 1.4 & 130 & 5.2 & 0 & 0.6 & 0.19 & 3 & 100 & 0 \\
\hline Lentils & 340 & 20 & 0.6 & 51 & 9 & 0 & 0.5 & 0.25 & 2.6 & $\mathrm{U}$ & 0 \\
\hline
\end{tabular}

U - Unknown

Sources: $[4,5]$ 


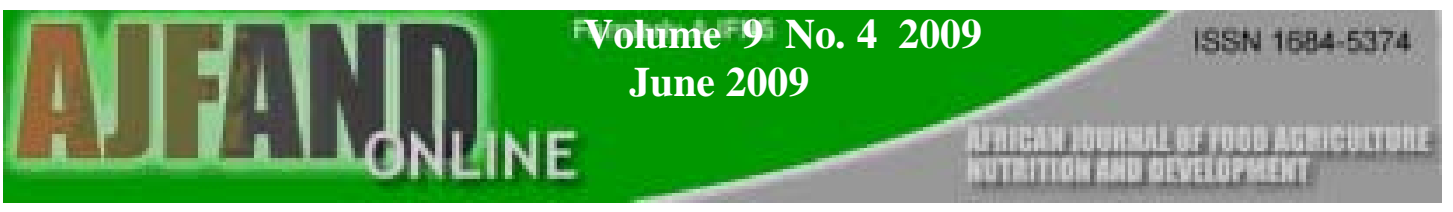

Table 2: Agencies that Responded to Requests for Information

\section{Agency name}

The World Food Programme

World Vision

Catholic Relief Services

Africare

Save the Children

The Micronutrient Initiative

UNICEF 
Table 3: Studies of vitamin A deficiency (VAD) in food aid beneficiaries

\begin{tabular}{|c|c|c|c|c|c|}
\hline Location & Population studied & $\begin{array}{c}\text { Sample } \\
\text { size }\end{array}$ & Indicator(s) & $\begin{array}{c}\text { Prevalence } \\
(\%)\end{array}$ & Reference \\
\hline Fugnido camp, & Refugee children, 6- & 124 & VAD & 43.6 & [11] \\
\hline \multirow[t]{2}{*}{ Ethiopia } & 59 months & & $\begin{array}{l}\text { (Serum retinol } \\
\text { concentration }<0.70 \\
\mu \mathrm{mol} / \mathrm{L})\end{array}$ & & \\
\hline & & & $\begin{array}{l}\text { Medium risk for } \\
\text { VAD } \\
\text { (Serum retinol } \\
\text { concentration } 0.35- \\
0.70 \mu \mathrm{mol} / \mathrm{L} \text { ) }\end{array}$ & 40.3 & \\
\hline Kebribeyah camp, & Refugee children, 6- & 151 & VAD & 20.5 & [11] \\
\hline Ethiopia & 59 months & & $\begin{array}{l}\text { (Serum retinol } \\
\text { concentration }<0.70 \\
\mu \mathrm{mol} / \mathrm{L})\end{array}$ & & \\
\hline & & & $\begin{array}{l}\text { Medium risk for } \\
\text { VAD } \\
\text { (Serum retinol } \\
\text { concentration } 0.35- \\
0.70 \mu \mathrm{mol} / \mathrm{L} \text { ) }\end{array}$ & 19.9 & \\
\hline
\end{tabular}

$\begin{array}{llllll}\text { Kakuma camp, } & \text { Adolescent refugees } & 196 & \text { VAD } & 15 & \text { [13] }\end{array}$

Kenya

(Serum retinol

concentration $<0.70$

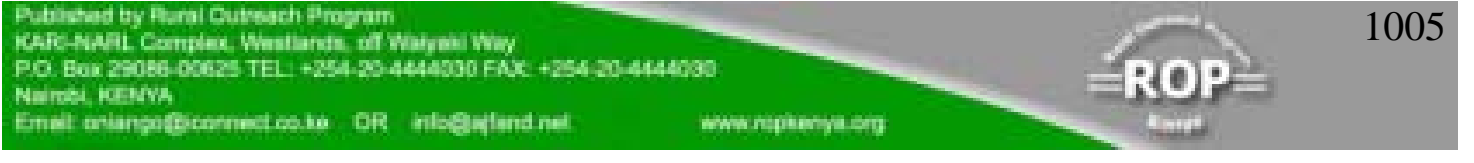


$\mu \mathrm{mol} / \mathrm{L})$

Night blindness

24

Kakuma camp, $\quad$ Refugee children, 6- $110 \quad$ VAD

Kenya

59 months

(Serum retinol

concentration $<0.70$

$\mu \mathrm{mol} / \mathrm{L})$

Medium risk for

46.4

VAD

(Serum retinol

concentration $0.35-$

$0.70 \mu \mathrm{mol} / \mathrm{L}$ )

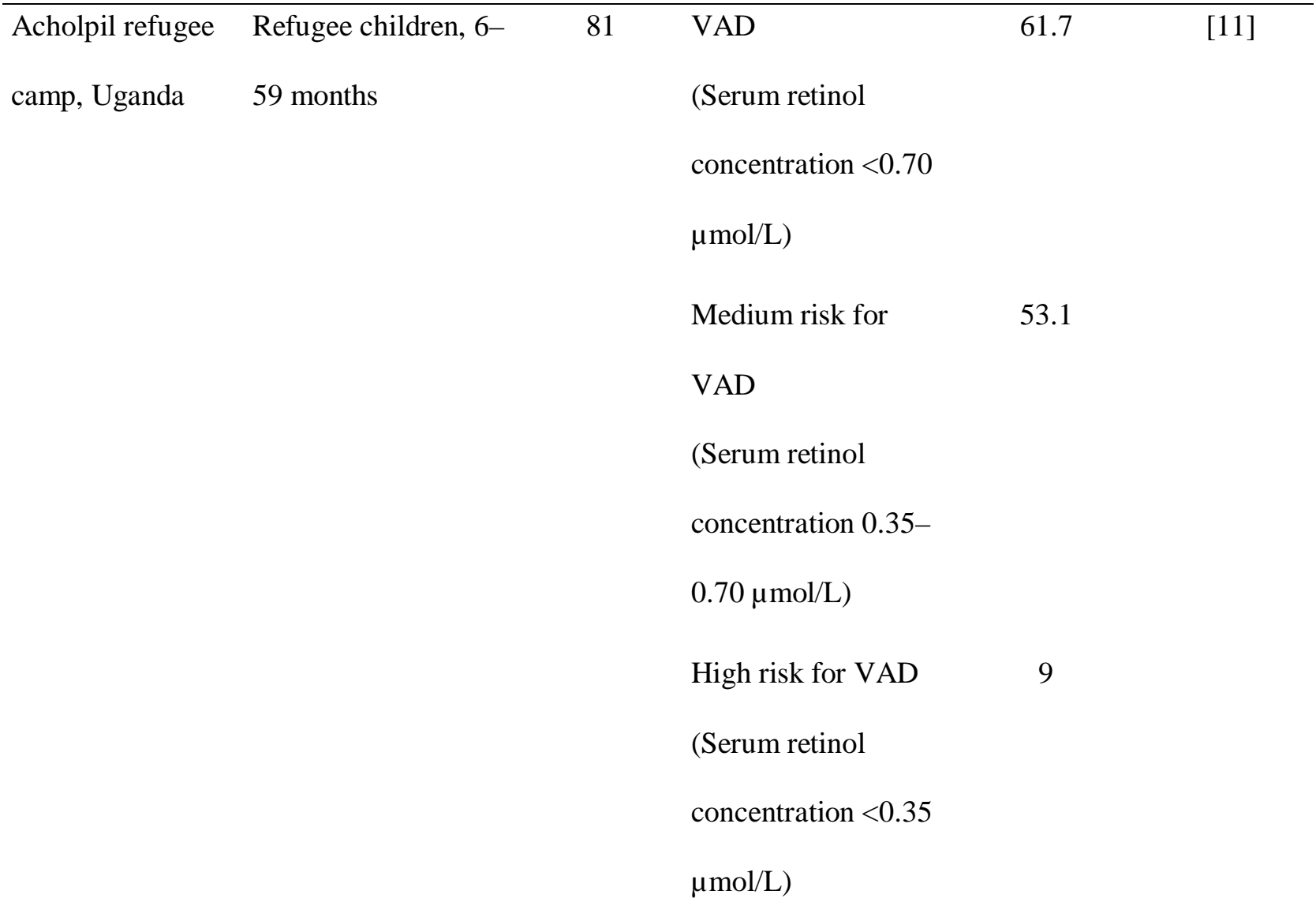




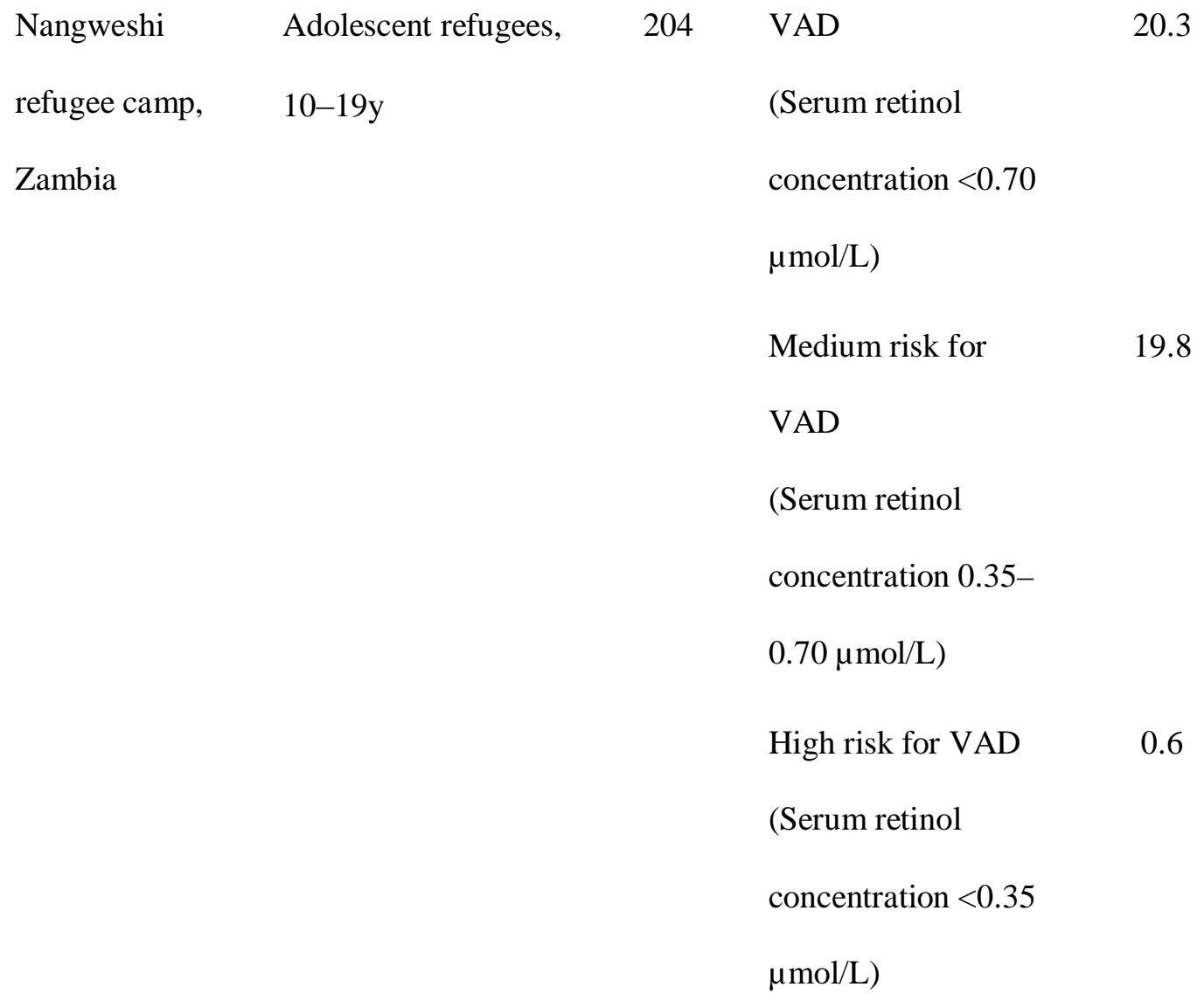


Table 4: Prevalence rates $(\%)$ of deficiencies in the general population in children less than 5 years old

$\begin{array}{ccc}\text { Night blindness } & \text { Bitot's spots } & \text { Vitamin A deficiency (Serum } \\ (\%) & (\%) & \text { retinol concentration }<0.70 \\ & & \mu \mathrm{mol} / \mathrm{L}),\end{array}$

$(\%)$

\begin{tabular}{|c|c|c|c|}
\hline Ethiopia & $4.7-7.2$ & 2.2 & 61.2 \\
\hline Kenya & 1.5 & $0.6-2.0$ & $41-90.6$ \\
\hline Uganda & - & - & 28 \\
\hline Rwanda & - & - & $21^{\mathrm{a}}$ \\
\hline Zambia & $0.6^{\mathrm{c}}$ & 0.6 & 54.1 \\
\hline Zimbabwe $^{b}$ & - & - & 35.8 \\
\hline Niger & 2.1 & - & 23.8 \\
\hline \multicolumn{4}{|c|}{$\begin{array}{l}{ }^{\mathrm{a}} \text { Infants, } 6-12 \text { months, cut-off level for deficiency was serum retinol concentration } \\
<20 \mu \mathrm{g} / \mathrm{dL} \\
{ }^{\mathrm{b}} \text { Data listed for Zimbabwe does not reflect the recent political situation and its impact } \\
\text { on nutritional status } \\
{ }^{\mathrm{c}} \text { Children, } 24-71 \text { months } \\
\text { Data sources: }[11,12,15-34]\end{array}$} \\
\hline
\end{tabular}


Table 5: Studies of anemia and iron status in food aid beneficiaries

\begin{tabular}{|c|c|c|c|c|c|}
\hline Location & Population studied & $\begin{array}{c}\text { Sample } \\
\text { size }\end{array}$ & Indicator(s) & $\begin{array}{c}\text { Prevalence } \\
(\%)\end{array}$ & Reference \\
\hline Kebribeyha camp, & Somali refugee & n not & IDA, indicator not & 12.8 & 2001 micronutrient \\
\hline \multirow[t]{2}{*}{ Ethiopia } & children, 6-59 & specified & specified & & survey cited in [3] \\
\hline & months & & & & \\
\hline \multirow[t]{2}{*}{ Pugnido camp, Ethiopia } & Sudanese refugees & n not & IDA, indicator not & 65.1 & 2001 micronutrient \\
\hline & & specified & specified & & survey cited in [3] \\
\hline \multirow[t]{7}{*}{ Fugnido camp, Ethiopia } & Refugee children, & 202 & Anemia $(\mathrm{Hb}<11.0$ & 62.9 & [11] \\
\hline & $6-59$ months & & $\mathrm{g} / \mathrm{dL})$ & & \\
\hline & & & Severe anemia $(\mathrm{Hb}$ & 9.4 & \\
\hline & & & $<7.0 \mathrm{~g} / \mathrm{dL})$ & & \\
\hline & & & Iron deficiency & 65 & \\
\hline & & & ( sTfR cut-off $>8.5$ & & \\
\hline & & & $\mathrm{mg} / \mathrm{L})$ & & \\
\hline Kebribeyah camp, & Refugee children, & 210 & Anemia $(\mathrm{Hb}<11.0$ & 12.8 & [11] \\
\hline \multirow[t]{6}{*}{ Ethiopia } & $6-59$ months & & $\mathrm{g} / \mathrm{dL})$ & & \\
\hline & & & Severe anemia $(\mathrm{Hb}$ & 1 & \\
\hline & & & $<7.0 \mathrm{~g} / \mathrm{dL})$ & & \\
\hline & & & Iron deficiency & 22.6 & \\
\hline & & & (sTfR cut-off $>8.5$ & & \\
\hline & & & $\mathrm{mg} / \mathrm{L})$ & & \\
\hline
\end{tabular}




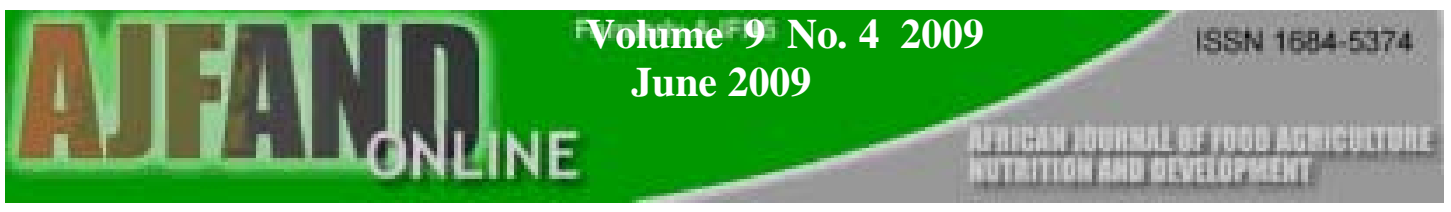

Fugnido camp, Ethiopia Adolescents

157 Anemia $(\mathrm{Hb}<11.0$

11.5

[11]

refugees, 10-19y

$\mathrm{g} / \mathrm{dL})$

Fugnido camp, Ethiopia Non-pregnant

98 Anemia $(\mathrm{Hb}<11.0$

14.2

refugee women,

$\mathrm{g} / \mathrm{dL})$

$20-55 y$

Kakuma camp, Turkana Refugee children,
District, Kenya
6-59 months

Anemia $(\mathrm{Hb}<11.0$

66.2

[11]

$\mathrm{g} / \mathrm{dL})$

Severe anemia $(\mathrm{Hb}$

1.3

$<7.0 \mathrm{~g} / \mathrm{dL})$

Iron deficiency

9.8

(sTfR cut-off $>8.5$

$\mathrm{mg} / \mathrm{L}$ )

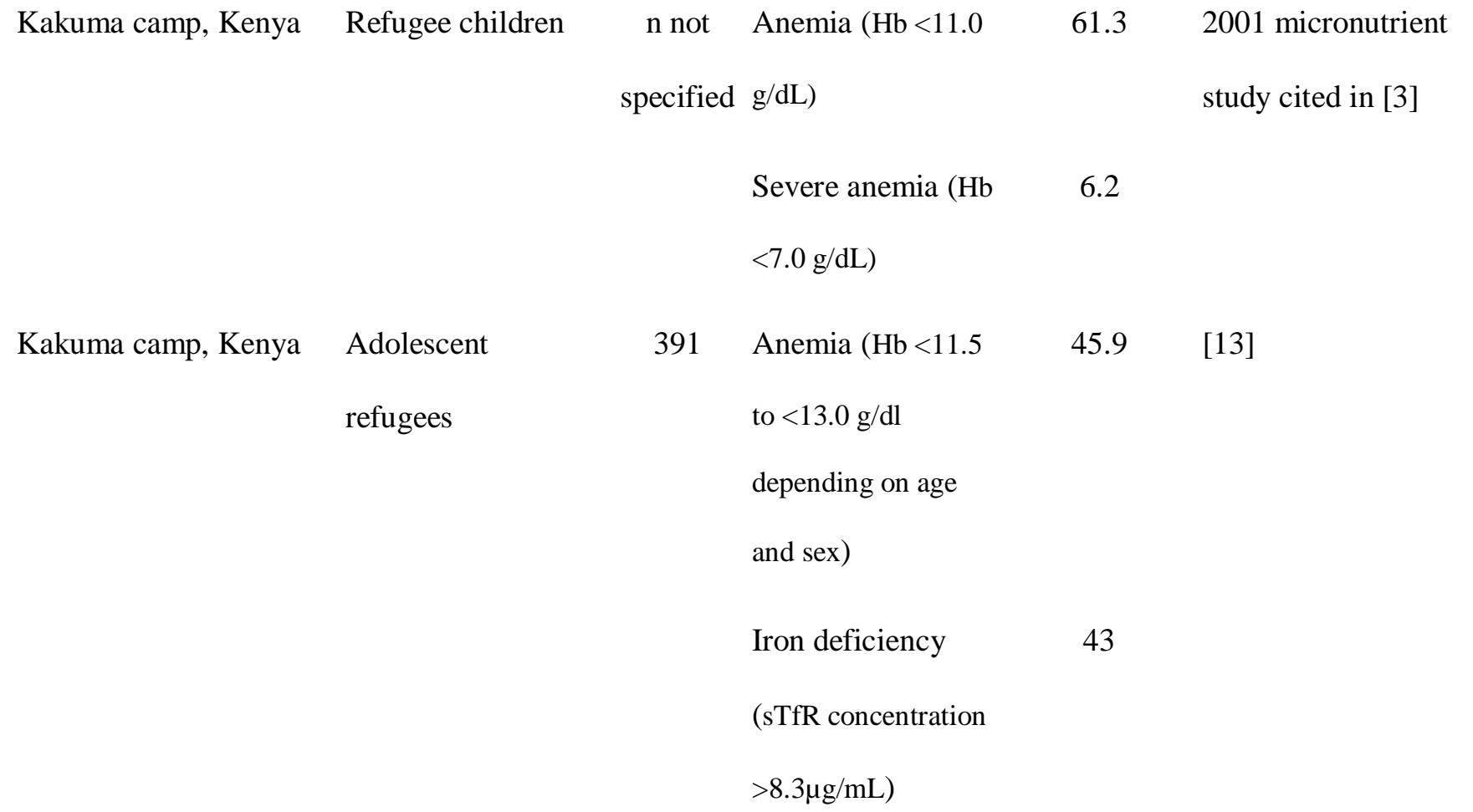

$>8.3 \mu \mathrm{g} / \mathrm{mL})$ 


\begin{tabular}{|c|c|c|c|c|c|}
\hline Dadaab camp, Garissa & Pregnant women & n not & Anemia, cut-off & 75 & 2001 micronutrient \\
\hline district, Kenya & & specified & not specified & & study cited in [3] \\
\hline
\end{tabular}

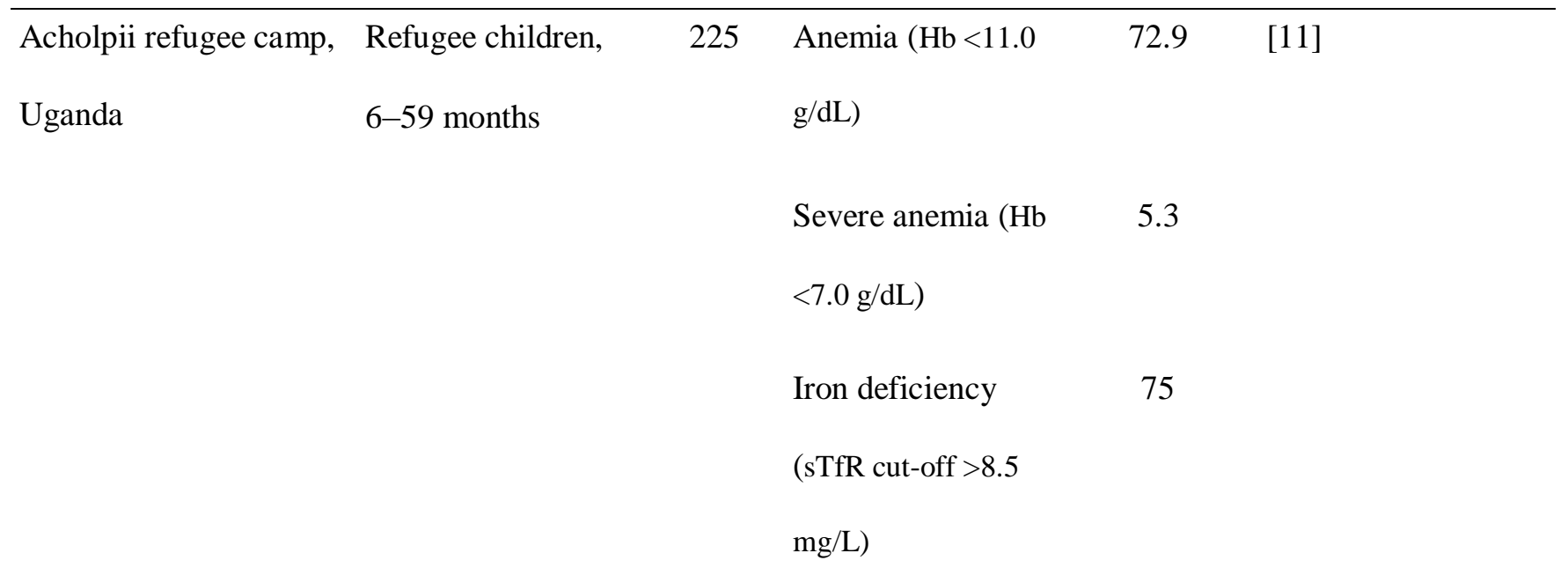

Adolescents $\quad 223 \quad$ Anemia $(\mathrm{Hb}<11.0 \quad 32.7 \quad[11]$

refugees, 10-19y $\quad \mathrm{g} / \mathrm{dL})$

Non-pregnant $\quad 192 \quad$ Anemia $(\mathrm{Hb}<11.0 \quad 31.3 \quad[11]$

women $20-55 \mathrm{y} \quad \mathrm{g} / \mathrm{dL})$

\begin{tabular}{llllll}
\hline Nangweshi refugee & Refugee children, & 136 & Total anemia & 24.3 & [14]
\end{tabular}

camp, Zambia $\quad 6-59$ months

$\begin{array}{lll} & \text { Mild anemia }(\mathrm{Hb} & 10.3 \\ & 10-10.9 \mathrm{~g} / \mathrm{dL}) & \\ & \text { Moderate anemia } & 12.5 \\ & (\mathrm{Hb} 7-9.9 \mathrm{~g} / \mathrm{dL}) & \\ & \text { Severe anemia }(\mathrm{Hb} & 1.5 \\ & <7.0 \mathrm{~g} / \mathrm{dL}) \\ & & \\ \text { Adolescent } & \text { Total anemia } & 24.4 \quad[14]\end{array}$


refugees, 10-19y

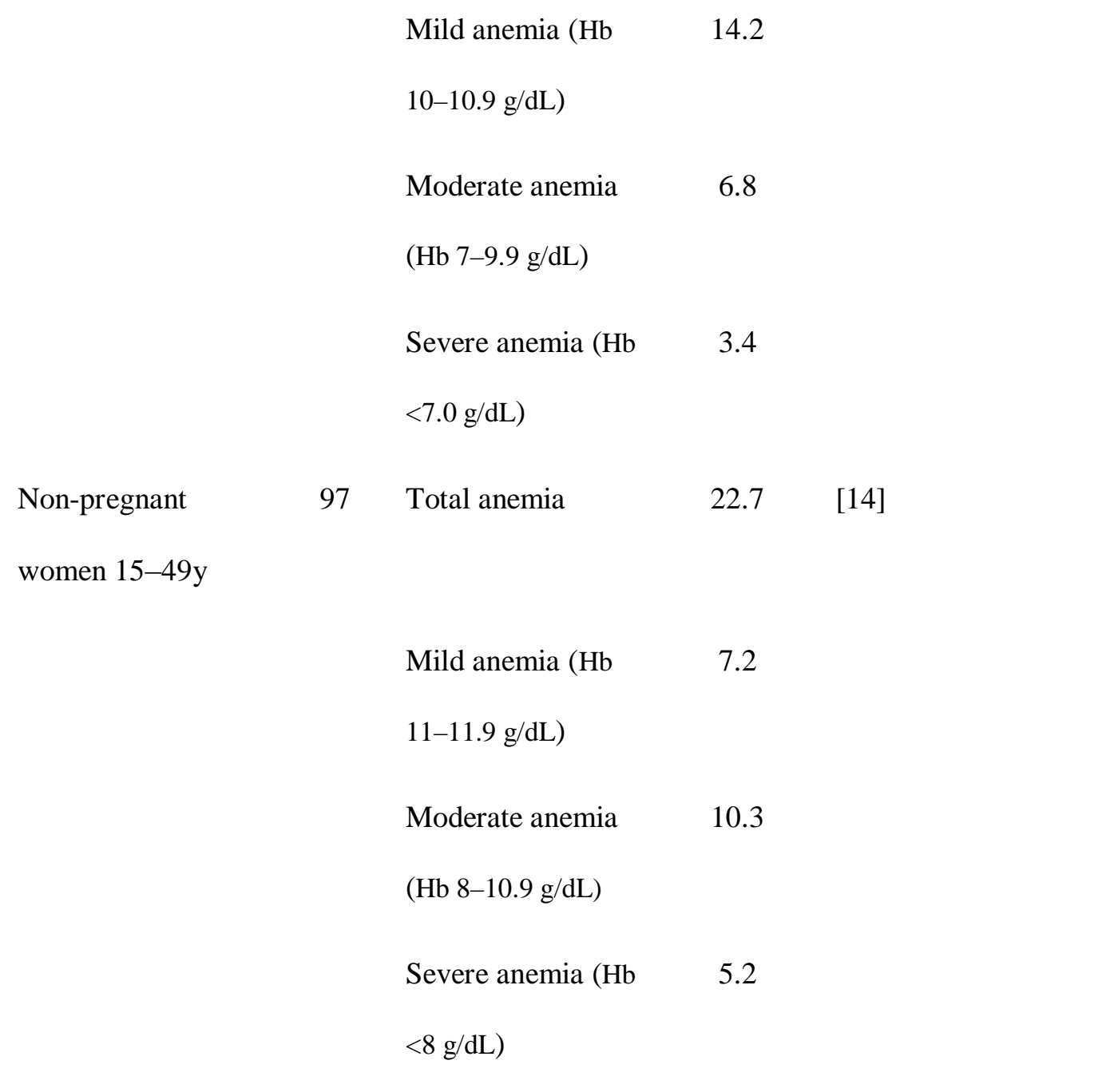

IDA: Iron deficiency anemia

Hb: Hemoglobin

sTfR: serum-soluble transferrin receptor 
Table 6: Prevalence rates (\%) of anemia and iron deficiency in the general population

\begin{tabular}{lccc}
\hline & Iron deficiency & Anemia, children, & Anemia, women \\
& $(\boldsymbol{\%})$ & $\mathbf{6 - 5 9}$ mos. & $(\boldsymbol{\%})$ \\
& - & $(\boldsymbol{\%})$ & 27 \\
\hline Ethiopia & $20^{\mathrm{a}}$ & 54 & 49 \\
Kenya & - & $17-98^{\mathrm{b}}$ & 30 \\
Uganda & - & 64 & 33 \\
Rwanda & $41^{\mathrm{c}}$ & 56 & 29 \\
Zambia & - & 53 & 38 \\
Zimbabwe & - & 58 & 46 \\
Niger & - & 84 & \\
\hline
\end{tabular}

- No data available

${ }^{\mathrm{a}}$ Children, deficiency defined as serum ferritin concentration $<12 \mu \mathrm{g} / \mathrm{dL}$

${ }^{\mathrm{b}}$ Data from a national sample of children ages 6-72 months old, $17 \%$ prevalence in the central highlands with $98 \%$ prevalence in the coastal regions

${ }^{\mathrm{c}}$ Women, deficiency defined as serum iron concentration $<7 \mu \mathrm{g} / \mathrm{dL}$

${ }^{\mathrm{d}}$ Data listed for Zimbabwe does not reflect the recent political situation and its impact on nutritional status

Data sources: [16-25] 
Table 7: Prevalence rates $(\%)$ of deficiencies in the general population Iodine deficiency, $\mathrm{UI}<\mathbf{1 0 0} \mu \mathrm{g} / \mathrm{L}$

$(\%)$

\begin{tabular}{lc}
\hline Ethiopia & $68.4^{\mathrm{a}}$ \\
Kenya & 36.7 \\
Uganda & 11.9 \\
Rwanda & 0 \\
Zambia & 72.0 \\
Zimbabwe & 14.8 \\
Niger & - \\
\hline
\end{tabular}

UI: Urinary iodine concentration

- No data available

${ }^{\mathrm{a}}$ Children

Data sources: [27, 40-44] 


\section{REFERENCES}

1. World Food Programme, United Nations High Commission for Refugees Acute Malnutrition in Protracted Refugee Situations: A Global Strategy. Rome: UNHCR/WFP; 2006.

2. World Food Programme Food Assistance to Sudanese, Somali, and Eritrean Refugees. Available at: http://www.wfp.org/operations/current operations/project docs/101272.pdf. Accessed 18 July 2007.

3. World Food Programme and United Nations High Commissioner for Refugees Report of the Food Consumption Survey in Dadaab and Kakuma Refugee Camps. Nairobi: World Food Programme; 2004 March.

4. United Nations High Commissioner for Refugees Handbook for Emergencies. 2nd edition. United Nations High Commissioner for Refugees, Geneva. 1999.

5. Food and Agriculture Organization of the United Nations Food and Nutrition in the Management of Group Feeding Programmes. Rome; 1993.

6. Weise Prinzo $\mathbf{Z}$ and $\mathbf{B}$ de Benoist Meeting the Challenges of Micronutrient Deficiencies in Emergency-Affected Populations. Proc Nutr Soc 2002; 61: 251-257.

7. Kennedy G, Nantel G and P Shetty The Scourge of "Hidden Hunger": Global Dimensions of Micronutrient Deficiencies. Food, Nutrition and Agriculture 2003; 32: 8-16.

8. Wuehler SE, Peerson JM and KH Brown Use of National Food Balance Data to Estimate the Adequacy of Zinc in National Food Supplies: Methodology and Regional Estimates. Public Health Nutr 2005; 8(7): 812819.

9. Gibson RS Zinc Nutrition in Developing Countries. Nutr. Res. Rev 1994; 7: 151-173.

10. WHO. Indicators for Assessing Vitamin A Deficiency and their Application in Monitoring and Evaluating Intervention Programmes. Geneva: World Health Organization; 1996.

11. Seal AJ, Creeke PI, Mirghani Z, Abdalla F, McBurney RP, Pratt LS, Brookes D, Ruth LJ and E Marchand Iron and Vitamin A Deficiency in Long-Term African Refugees. J. Nutr. 2005; 135(4): 808-813. 
12. Administration for Refugee and Returnee Affairs, United Nations High Commission for Refugees and World Food Programme 2003 Joint Assessment Mission. Rome: World Food Programme; 20037 to 14 July 2003.

13. Woodruff BA, Blanck HM, Slutsker L, Cookson ST, Larson MK, Duffield A and R Bhatia Anaemia, Iron Status and Vitamin A Deficiency among Adolescent Refugees in Kenya and Nepal. Public Health Nutr 2006; 9(1): 2634.

14. United Nations ACC/Sub-Committee on Nutrition Zambia. Nutrition in Crisis Situations, Volume 7 Available at: http://www.unsystem.org/scn/archives/nics07/index.htm. Accessed July 2007.

15. Republic of Rwanda Ministry of Health National Nutrition Policy. Kigali, Rwanda: Ministry of Health; 2005 October.

16. Siekmann JH, Allen LH, Bwibo NO, Demment MW, Murphy SP and CG Neumann Kenyan School Children Have Multiple Micronutrient Deficiencies, but Increased Plasma Vitamin B-12 Is the Only Detectable Micronutrient Response to Meat or Milk Supplementation. J Nutr 2003; 133(11 Suppl 2): 3972S-3980S.

17. Uganda Bureau of Statistics (UBOS) and ORC Macro Uganda Demographic and Health Survey 2000-2001. Calverton, Maryland, USA: UBOS and ORC Macro; 2001.

18. Institut National de la Statistique [Niger], Ministere de l'Economie et des Finances and Macro International Inc. Enquête Démographique Et De Santé Et À Indicateurs Multiples 2006. Niamey, Niger: Institut National de la Statistique [Niger], Ministere de l'Economie et des Finances, and Macro International Inc.; 2007.

19. Central Statistical Agency [Ethiopia], ORC Macro Ethiopia Demographic and Health Survey 2005. Addis Ababa, Ethiopia and Calverton, Maryland, USA: Central Statistical Agency and ORC Macro; 2006.

20. Kenya Medical Research Institute, UNICEF, Ministry of Health, University of Nairobi, Social Science and Medicine-Africa Network Anaemia and Status of Iron, Vitamin A and Zinc in Kenya: The 1999 National Survey. Nairobi: Kenya Medical Research Institute, UNICEF, Ministry of Health, University of Nairobi, Social Science and Medicine-Africa Network; 2000 .

21. Mason J, Bailes A, Beda-Andourou M, Copeland N, Curtis T, Deitchler M, Foster L, Hensley M, Horjus P, Johnson C, Lloren T, Mendez A, Munoz M, Rivers J and $\mathbf{G}$ Vance Recent Trends in Malnutrition in Developing Regions: Vitamin A Deficiency, Anemia, Iodine Deficiency, and Child Underweight. Food Nutr Bull 2005; 26(1): 59-108.

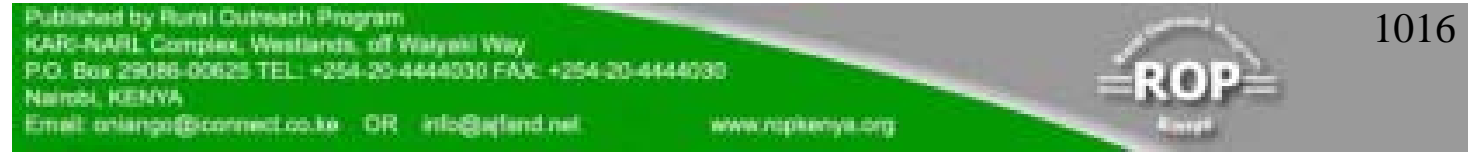


22. Institut National de la Statistique du Rwanda (INSR) and ORC Macro Rwanda Demographic and Health Survey 2005. Calverton, Maryland, USA: INSR and ORC Macro; 2006.

23. Micronutrient Operational Strategies and Technologies (MOST), UNICEF, Centers for Disease Control and Prevention and Food and Nutrition Commission of Zambia Report of the National Survey to Evaluate the Impact of Vitamin A in Zambia. Zambia: MOST, United States Agency for International Development (USAID) Micronutrient Program; 2003.

24. Kafwembe EM Iron and Vitamin A Status of Breastfeeding Mothers in Zambia. East Afr Med J 2001; 78(9): 454-457.

25. Central Statistical Office (CSO) [Zimbabwe] and Macro International Inc. Zimbabwe Demographic and Health Survey 2005-2006. Calverton, Maryland: CSO and Macro International Inc.; 2007.

26. Ncube TN, Malaba L, Greiner T and M Gebre-Medhin Evidence of Grave Vitamin A Deficiency among Lactating Women in the Semi-Arid Rural Area of Makhaza in Zimbabwe. A Population-Based Study. Eur J Clin Nutr 2001; 55(4): 229-234.

27. Ministère de la Santé Rwanda, UNICEF and WHO National Nutrition Survey of Women and Children in Rwanda in 1996: Final Report. Kigali: Ministère de la Santé; 1997.

28. West KPJ, Rice A and J Sugimoto Tables on the Global Burden of Vitamin A Deficiency and Xerophthalmia among Preschool Aged Children and Low Vitamin A Status, Vitamin A Deficiency and Maternal Night Blindness among Pregnant Women by WHO Region. Available at: http://www.jhsph.edu/CHN/GlobalVAD.pdf. Accessed 26 July 2007.

29. Asrat YT, Omwega AM and JW Muita Prevalence of Vitamin A Deficiency among Pre-School and School-Aged Children in Arssi Zone, Ethiopia. East Afr Med J 2002; 79(7): 355-359.

30. Bergeron G, Deitchler M and J Pender Report on the 2003 Joint Baseline Survey in the Targeted Areas of the PL480, Title II Program in Ethiopia. Washington, D.C.: Food and Nutrition Technical Assistance (FANTA) Project and Academy for Educational Development (AED); 2004 June.

31. République du Niger and UNICEF Enquête À Indicateurs Multiples De La Fin De La Décennie (MICS). Niamey: United Nations Children's Fund; 2000.

32. Helen Keller International and World Food Programme Evaluation De Base De L'état Nutritionnel Des Enfants De 6 À 59 Mois Dans Les Régions Rurales De Maradi Et De Zinder. Hellen Keller International and World Food Programme; 2005. 
33. Munene RM, Adala HS, Masinde MS and FS Rana Vitamin A Deficiency among Kenyan Children as Detected by Conjunctival Impression Cytology. East Afr Med J 2003; 80(9): 476-479.

34. World Vision Canada Vitamin A Add-on Program: Final Survey and Program Report. Mississauga, Ontario: World Vision Canada; 2005.

35. Sommer A and FR Davidson Assessment and Control of Vitamin A Deficiency: The Annecy Accords. J Nutr 2002; 132(9 Suppl): 2845S-2850S

36. WHO. Iron Deficiency Anemia: Assessment, Prevention, and Control: A Guide for Programme Managers. Geneva: World Health Organization; 2001.

37. World Health Organization, United Nations High Commissioner for Refugees, International Federation of Red Cross and Red Crescent Societies and World Food Programme The Management of Nutrition in Major Emergencies. World Health Organization, Geneva. 2000.

38. WHO. Assessment of Iodine Deficiency Disorders and Monitoring Their Elimination: A Guide for Programme Managers. 2nd edition. World Health Organization, Geneva. 2001.

39. Seal AJ, Creeke PI, Gnat D, Abdalla $\mathbf{F}$ and $\mathbf{Z}$ Mirghani Excess Dietary Iodine Intake in Long-Term African Refugees. Public Health Nutr 2006; 9(1): 35-39.

40. Government of Zimbabwe. National Micronutrient Survey: 1999. Harare: Ministry of Health and Child Welfare; 2001c.

41. Cherinet A and U Kelbessa Determinants of Iodine Deficiency in School Children in Different Regions of Ethiopia. East Afr Med J 2000; 77: 133-137.

42. Gitau W Report of the National Micronutrient Survey - February to August 1994, Iodine Deficiency Disorders. Nairobi: University of Nairobi; 1994.

43. Lumbwe CM, Chowa V, Maonde N, Nyirongo W and R Gutekunst Iodine Deficiency Disorders in Zambia - 1993 Survey Draft Report. Lusaka: National Food and Nutrition Commission; 1995.

44. Okui O, Bimenya GS, Kaviri D and N Bbona Monitoring Progress Towards Control of IDD through Universal Salt Iodization in Uganda: Study Report. Kampala: Makerere University; 2000.

45. Abebe Y, Bogale A, Hambidge KM, Stoecker BJ, Arbide I, Teshome A, Krebs NF, Westcott JE, Bailey KB and RS Gibson Inadequate Intakes of Dietary Zinc among Pregnant Women from Subsistence Households in Sidama, Southern Ethiopia. Public Health Nutr 2007: 1-8. 
46. Umeta M, West CE, Verhoef H, Haidar J and JG Hautvast Factors Associated with Stunting in Infants Aged 5-11 Months in the Dodota-Sire District, Rural Ethiopia. J Nutr 2003; 133(4): 1064-1069.

47. Friis H, Gomo E, Koestel P, Ndhlovu P, Nyazema N, Krarup H and KF Michaelsen HIV and Other Predictors of Serum Folate, Serum Ferritin, and Hemoglobin in Pregnancy: A Cross-Sectional Study in Zimbabwe. Am J Clin Nutr 2001; 73(6): 1066-1073.

48. Ahoua L, Etienne W, Fermon F, Godain G, Brown V, Kadjo K, Bouaffou $\mathbf{K}$, Legros D and PJ Guerin Outbreak of Beriberi in a Prison in Cote D'ivoire. Food Nutr Bull 2007; 28(3): 283-290.

49. WHO. Thiamine Deficiency and Its Prevention and Control in Major Emergencies. Geneva: World Health Organization; 1999.

50. United Nations Administrative Committee on Coordination/SubCommittee on Nutrition (ACC/SCN) Third Report on the World Nutrition Situation. Geneva: ACC/SCN; 1997.

51. World Health Organization and Food and Agricultural Organization of the United Nations Guidelines on Food Fortification with Micronutrients. World Health Organization, Geneva. 2006.

52. Wacker J, Fruhauf J, Schulz M, Chiwora FM, Volz J and K Becker Riboflavin Deficiency and Preeclampsia. Obstet Gynecol 2000; 96(1): 38-44.

53. Berry-Koch A, Moench R, Hakewill P and M Dualeh Alleviation of Nutritional Deficiency Diseases in Refugees. Food and Nutrition Bulletin 1990; 12 (2): 106-112.

54. Savage D, Gangaidzo I, Lindenbaum J, Kiire C, Mukiibi JM, Moyo A, Gwanzura C, Mudenge B, Bennie A, Sitima J, Stabler SP and RH Allen Vitamin B12 Deficiency Is the Primary Cause of Megaloblastic Anaemia in Zimbabwe. Br J Haematol 1994; 86(4): 844-850.

55. United Nations ACC/Sub-Committee on Nutrition Refugee Nutrition Information System (Rnis), No. 25 - Report on the Nutrition Situation of Refugee and Displaced Populations. Geneva: ACC/SCN; 1998.

56. Belachew T, Nida H, Getaneh $T$, Woldemariam $D$ and $W$ Getinet Calcium Deficiency and Causation of Rickets in Ethiopian Children. East Afr Med J 2005; 82(3): 153-159.

57. Bwibo NO and CG Neumann Rickets in Pre-School Children in Child Survival Project. Kenya Pediatric Association Bi-Annual Conference. Mombasa, Kenya; 2003. 
58. Arnaud J, Prual A, Preziosi P, Favier A and S Hercberg Selenium Determination in Human Milk in Niger: Influence of Maternal Status. J Trace Elem Electrolytes Health Dis 1993; 7(4): 199-204.

59. Baeten JM, Mostad SB, Hughes MP, Overbaugh J, Bankson DD, Mandaliya K, Ndinya-Achola JO, Bwayo JJ and JK Kreiss Selenium Deficiency Is Associated with Shedding of HIV-1 Infected Cells in the Female Genital Tract. J Acquir Immune Defic Syndr 2001; 26(4): 360-364.

60. United Nations World Food Programme Kenya Country Office Reducing the Burden of HIV/AIDS: Experience of a Food Aid Intervention in Western Kenya. Nairobi: World Food Programme; 2005. 